\title{
PEMANFAATAN ABU CANGKANG KERANG DARAH (ANADARA GRANOSA) SEBAGAI KATALIS DALAM PEMBUATAN METIL ESTER DARI MINYAK JELANTAH
}

\author{
Bernandus Petrus, Andika Prasetyo Sembiring, Mersi Suriani Sinaga \\ Departemen Teknik Kimia, Fakultas Teknik, Universitas Sumatera Utara, \\ Jl. Almamater Kampus USU Medan 20155, Indonesia \\ Email: bernanduspetrus@gmail.com
}

\begin{abstract}
Abstrak
Transesterifikasi merupakan reaksi yang digunakan untuk memproduksi metil ester dimana reaksi ini melibatkan katalis dari abu cangkang kerang darah hasil pembakaran pada temperatur $900{ }^{\circ} \mathrm{C}$ selama 3 jam dan jumlah abu yang digunakan sebesar $8 \%, 10 \%, 12 \%(\mathrm{~b} / \mathrm{b})$. Abu yang digunakan di larutkan dalam metanol dengan rasio molar metanol:minyak sebesar 9:1, 12:1 (n/n) untuk mendapatkan senyawa kalsium metoksida. Minyak jelantah disaring kemudian diesterifikasi dengan katalis 3,0\% (b/b) $\mathrm{H}_{2} \mathrm{SO}_{4} 98 \%$ dan metanol: TG minyak (6:1) untuk menurunkan FFA menjadi <1\%. Reaksi transesterifikasi dilakukan pada temperatur reaksi $65^{\circ} \mathrm{C}$ selama 3 jam, dan pengadukan tetap $700 \mathrm{rpm}$. Secara kuantitatif, yield optimum metil ester yang dihasilkan adalah pada jumlah abu $12 \%$ (b/b) dan rasio molar metanol:minyak sebesar 12:1 (n/n) sebesar 56,51\% dengan spesifikasi metil ester seperti densitas, viskositas kinematik dan titik nyala sesuai dengan SNI 04-7182-2006 biodiesel dan berdasarkan analisa GC (Gas Chromatography), kemurnian metil ester yang dihasilkan adalah $98,79 \%$.
\end{abstract}

Kata kunci: minyak jelantah, katalis, esterifikasi, transesterifikasi, metil ester

\begin{abstract}
Transesterification is the reaction to produce methyl esters in which this reaction's involves catalyst of blood clam shell ashes of combustion at temperatures of $900^{\circ} \mathrm{C}$ for 3 hours and the amount of ash that is used by $8 \%, 10 \%, 12 \%(w / w)$. Ash used in dissolved in methanol with a molar ratio of methanol: oil of 9: $1,12: 1(n / n)$ to obtain a compound of calcium methoxide. Used cooking oil is filtered and then esterified with catalyst $3.0 \%(w / w) \mathrm{H}_{2} \mathrm{SO}_{4} 98 \%$ and methanol: oil TG (6: 1) to reduce the FFA to $<1 \%$. Transesterification reaction is carried out at a reaction temperature of $65^{\circ} \mathrm{C}$ for 3 hours, and keep stirring $700 \mathrm{rpm}$. Quantitatively, the optimum yield of methyl ester in the amount of ash produced is 12\% $(w / w)$ and the molar ratio of methanol: oil at 12: $1(n / n)$ of $56.51 \%$ with specification methyl esters such as density, kinematic viscosity and purity methyl ester biodiesel in accordance with SNI 04-71822006, based on the analysis of GC (Gas Chromatography), the purity of the resulting methyl ester was $98.79 \%$.
\end{abstract}

Keywords: used cooking oil, catalyst, esterification, transesterification, methyl ester

\section{Pendahuluan}

Menipisnya cadangan minyak bumi di dunia menjadi perhatian yang sangat serius dari berbagai kalangan. Oleh karena itu, penggunaan minyak bumi sebagai bahan bakar utama untuk berbagai macam kegiatan perlu dibatasi dan dicari sumber energy penggantinya. Berbagai macam penelitian tentang energy alternative telah dilakukan, salah satunya biodiesel. Biodiesel memiliki banyak keuntungan dibandingkan petroleum diesel. Biodiesel merupakan bahan yang bisa diperbaharui, rendah emisi, dan biodegradable. Biodiesel dapat diproduksi dengan proses transesterifikasi yang menggunakan minyak nabati yang direaksikan dengan metanol. Secara umum biodiesel (metil ester) yang dihasilkan menunjukan sifat yang sama sebagai bahan bakar convensional [4].

Produksi metil ester biasanya menggunakan katalis homogen. Dengan menggunakan katalis homogen baik asam atau basa, reaksi pembentukan metil ester akan berjalan cepat dan konversi reaksi juga tinggi. Tetapi salah satu kerugian dalam penggunaan katalis homogen adalah katalis tersebut sulit diregenerasi kembali, karena katalis bercampur dengan minyak dan metanol maka proses pemisahaan katalis dari produk lebih kompleks. Pengunaaan katalis ini juga tidak ramah lingkungan karena membutuhkan banyak air untuk proses pemisahaannya. Untuk mengatasi kelemahan dari katalis homogen tersebut penelitian untuk mengembangkan katalis alternatif telah banyak dilakukan dan fokusnya adalah pengembangan katalis heterogen. Beberapa katalis heterogen yang telah digunakan pada pembuatan metil ester adalah $\mathrm{KNO}_{3} / \mathrm{Al}_{2} \mathrm{O}_{3}, \mathrm{MgO}, \mathrm{SrO}, \mathrm{CaO}$, dll. $\mathrm{CaO}$ lebih banyak digunakan karena $\mathrm{CaO}$ tergolong bahan ramah lingkungan. Pemanfaatan $\mathrm{CaO}$ yang diperoleh dari limbah kerang telah banyak dipelajari belakangan ini seperti kerang tiram, kerang darah, kerang batik, cangkang kepiting lumpur, dan golden apple, snail shell telah digunakan sebagai sumber bahan baku $\mathrm{CaO}$ dan dievaluasi keefektifannya sebagai katalis pembuatan metil ester [4]. 
Menurut statistik perikanan tangkap Indonesia jumlah kerang darah yang di hasilkan sebanyak 34382 ton/tahun, pemanfaatan cangkang kerang sebagai katalis dalam pembuatan metil ester untuk mengurangi limbah perairan. Cangkang kerang darah mengandung kalsium karbonat $\left(\mathrm{CaCO}_{3}\right)$, pembakaran cangkang kerang selain menghasilkan abu akan mengubah kandungan yang terdapat di abu cangkang yang mengandung $\mathrm{CaO}$ sebesar 69,02\%. Abu kerang yang mengandung $\mathrm{CaO}$ direaksikan dengan metanol $\left(\mathrm{CH}_{3} \mathrm{OH}\right)$ akan membentuk kalsium metoksida $\left(\mathrm{Ca}\left(\mathrm{OCH}_{3}\right)_{2}\right)$ yang dapat mempercepat reaksi transesterifikasi minyak nabati pada pembuatan metil ester [11].

Aldes, dkk membuat metil ester dari minyak jelantah dengan menggunakan kerang darah pada $900^{\circ} \mathrm{C}$ sebagai katalis dengan prosedur yang diperkenalkan oleh viriya-empikul yang terdiri dari beberapa tahapan proses yaitu proses transesterifikasi, esktraksi, dan proses destilasi untuk mendapatkan metil ester murni, dimana Aldes, dkk tidak melakukan variasi variabel operasi. Minyak jelantah yang memiliki kandungan asam lemak bebas (ALB) yang tinggi yang jika ditransesterifikasi dengan katalis abu kerang (bersifat basa) akan membentuk sabun, maka perlu terlebih dahulu dilakukan proses esterifikasi sebelum proses transesterifikasi [3].

Dengan mempertimbangkan hal-hal tersebut, perlu di lakukan penelitian pemanfaatan abu kerang darah sebagai katalis dalam pembuatan metil ester dari minyak jelantah dengan proses esterifikasi dan transesterifikasi sehingga diperoleh metil ester dengan jumlah yang besar dan abu kerang darah sebagai subtitusi katalis heterogen.

\section{Teori}

Biodiesel (metil ester) merupakan energi terbarukan yang dapat diperbaharui, bersifat biodegradable, ramah lingkungan karena hampir tidak ada membuang gas karbon monoksida (CO), karbon dioksida $\left(\mathrm{CO}_{2}\right)$, sulfur dioksida $\left(\mathrm{SO}_{2}\right)$, hidrokarbon (HC) dan partikel-partikel lain yang mengganggu pernafasan [7]. Abu cangkang kerang memiliki kadar kalsium oksida $(\mathrm{CaO})$ yang tinggi. Senyawa utama penyusun katalis abu dapat dilihat pada tabel 1.

Tabel 1. Senyawa utama Abu Cangkang kerang

\begin{tabular}{|c|c|}
\hline Komponen & Konsentrasi (\%) \\
\hline $\mathrm{CaO}$ & 69,02 \\
Kadar air & 0,02 \\
\hline
\end{tabular}

Dari tabel 1 di atas dapat di lihat bahwa kalsium oksida merupakan senyawa utama dalam abu cangkang kerang sebesar 69,02\% (b/b). Fungsi katalisator adalah mengaktifkan zat pereaksi sehingga pada kondisi tertentu konstanta kecepatan reaksi bertambah besar. Kalium hidroksida $(\mathrm{KOH})$ merupakan katalis yang sering di gunakan dalam metanolisis ataupun etanolisis minyak mentah dan minyak kelapa yang memberikan yield sebesar 90\%. Namun, penggunaan katalis homogen mempunyai kelemahan yaitu bersifat korosif, sulit dipisahkan dari produk dan katalis tidak dapat digunakan kembali [9].

Saat ini banyak industri menggunakan katalis heterogen yang mempunyai banyak keuntungan dan sifatnya yang ramah lingkungan, yaitu tidak bersifat korosif, mudah dipisahkan dari produk dengan cara filtrasi, serta dapat digunakan berulangkali dalam jangka waktu yang lama. Selain itu katalis heterogen meningkatkan kemurnian hasil karena reaksi samping dapat dieliminasi. Pemisahan katalis heterogen ini dari produk reaksinya dapat dilakukan dengan mudah. Abu yang mengandung senyawa kalsium oksida dilarutkan dalam metanol akan membentuk kalsium metoksida $\left(\mathrm{Ca}\left(\mathrm{OCH}_{3}\right)_{2}\right)$ yang digunakan sebakai katalis dalam proses transesterifikasi [11].

Minyak jelantah memiliki kadar asam lemak bebas (ALB) yang tinggi. Maka perlu dilakukan esterifikasi asam lemak bebas dengan katalis asam seperti asam sulfat untuk menjadi metil ester. Reaksi esterifikasi dapat di lihat pada gambar 1 .

$\underset{\mathrm{ALB}}{\mathrm{R}-\mathrm{COOH}}+\underset{\text { Metanol }}{\mathrm{CH}_{3} \mathrm{OH}} \stackrel{\text { Katalis }}{\rightleftarrows} \underset{\substack{\text { Metil Ester Air } \\ \text { R-COOCH}}}{\mathrm{H}_{2} \mathrm{O}}$

Gambar 1. Reaksi Esterifikasi dari Asam Lemak menjadi Metil Ester [12]

Transesterifikasi merupakan reaksi minyak dan lemak dengan alkohol untuk membentuk ester dan gliserol. Reaksi transesterifikasi dapat di lihat pada gambar 2 .

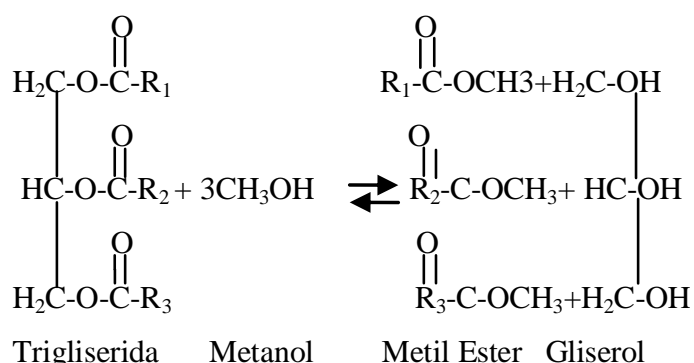

Gambar 2. Reaksi Transesterifikasi dari Trigliserida menjadi Metil Ester [12] 
Katalis biasanya di gunakan untuk mempercepat laju reaksi dan yield. Alkohol berlebih juga di gunakan untuk kesetimbangan sehingga rekasi bergeser ke arah produk karena ini merupakan reaksi reversibel. Jadi, ketika $\mathrm{NaOH}, \mathrm{KOH}$, atau sejenisnya dicampur dengan alkohol maka akan terbentuk larutan alkalinitas. Metanol $\left(\mathrm{CH}_{3} \mathrm{OH}\right)$, etanol $\left(\mathrm{C}_{2} \mathrm{H}_{5} \mathrm{OH}\right)$, propanol $\left(\mathrm{C}_{3} \mathrm{H}_{7} \mathrm{OH}\right)$ dan butanol $\left(\mathrm{C}_{4} \mathrm{H}_{9} \mathrm{OH}\right)$ banyak digunakan dalam reaksi ini namun metanol lebih banyak digunakan karena harga lebih murah dibandingkan alkohol lain [9, 12].

\section{Metodologi Penelitian}

Alat

Beaker glass, Labu leher tiga, Corong Pemisah, Oven, Desikator, Piknometer, Erlenmeyer, Refluks Kondensor, Furnace, Satu set alat titrasi, Gelas Ukur, Termometer, Hot Plate, Viskosimeter Ostwald, Ball Mill, Kertas Saringan

\section{Bahan}

Bahan yang di gunakan sebagai katalis pada penelitian ini adalah abu cangkang kerang yang di ambil dari pasar tradisional sedangkan sebagai bahan baku pada pembuatan metil ester adalah minyak jelantah yang diperoleh dari cafe dan penjual gorengan. Penelitian ini di lakukan di Laboratorium Penelitian dan Laboratorium Proses Industri Kimia Departemen Teknik Kimia, Fakultas Teknik, Universitas sumatera Utara.

\section{Prosedur Kerja}

\section{Tahap Preparasi Abu Cangkang Kerang}

Cangkang kerang dicuci dengan air sampai bersih. Cangkang dikeringkan dalam oven pada suhu $110^{\circ} \mathrm{C}$ selama 24 jam, diamkan di desikator 1 selama 24 jam, dihaluskan dengan ball mill kemudian dikalsinasi dengan furnace pada suhu $900^{\circ} \mathrm{C}$ selama 3 jam, didiamkan di dalam desikator selama 24 jam, kemudian diayak 100 mesh [3].

\section{Proses Esterifikasi}

Sebanyak 150 gram minyak jelantah direaksikan dengan Metanol (perbandingan mol metanol:Minyak adalah 6:1) dan ditambah dengan katalis $3 \%$ (b/b) $\mathrm{H}_{2} \mathrm{SO}_{4} 98 \%$ direkasikan pada temperatur $60{ }^{\circ} \mathrm{C}$ selama 90 menit dengan kecepatan pengadukan $250 \mathrm{rpm}$. Setelah reaksi dicapai, sampel dimasukkan dalam corong pemisah dan didiamkan pada suhu kamar selama 2 jam hingga terbentuk dua lapisan kemudian di pisahkan lapisan ester dan air. Sampel hasil esterifikasi dianalisa hingga $\mathrm{FFA}<1 \%$ dan dipanaskan dalam oven pada suhu $110{ }^{\circ} \mathrm{C}$ hingga berat konstan [8].

\section{Proses Transesterifikasi}

Ditimbang $8 \%(\mathrm{~b} / \mathrm{b})$ abu cangkang kerang di aduk dengan rasio molar metanol:minyak 9:1 ke dalam beaker glass lalu di aduk dan didiamkan selama 24 jam. Sampel hasil esterifikasi minyak jelantah di masukkan ke dalam labu leher tiga yang di lengkapi dengan termometer, motor pengaduk, dan refluks kondensor dan dipanaskan sampai suhu $60^{\circ} \mathrm{C}$ lalu dimaksukkan Campuran abu cangkang kerang dan metanol di masukkan ke dalam labu leher tiga yang berisi minyak. Campuran di panaskan sampai temperatur $65^{\circ} \mathrm{C}$ di atas hot plate dan dibiarkan bereaksi selama 3 jam pada temperatur konstan dan dengan pengadukan konstan yaitu $700 \mathrm{rpm}$. Campuran yang terbentuk dituang ke dalam corong pemisah yang beri kertas saring diatas dan di biarkan terjadi pemisahan selama 24 jam pada temperatur kamar. Lapisan bawah (gliserol) di buang sehingga yang tertinggal hanya lapisan atas yaitu metil ester. Metil ester di cuci dengan air hangat $\left(50^{\circ} \mathrm{C}\right)$ dalam corong pemisah untuk membuang residu katalis dan sabun. Pencucian ini dilakukan secara perlahan-lahan hingga lapisan air pencuci telah jernih. Setelah di cuci metil ester yang di hasilkan dikeringkan pada suhu $110{ }^{\circ} \mathrm{C}$ hingga tidak terlihat gelembung gas kemudian dihitung massanya. Prosedur proses transesterifikasi tersebut di lanjutkan dengan variasi jumlah katalis $10 \%$ dan $12 \%$ dan rasio molar metanol:minyak 9:1 [1, 4].

Hasil yang diperoleh kemudian di analisa secara kuantitatif dan kualitatif yaitu analisa yield, kemurnian, densitas, viskositas kinematik sesuai dengan SNI 04-7182-2006 yang di tunjukkan pada tabel 2 .

Tabel 2. Persyaratan Kualitas Biodiesel

\begin{tabular}{|l|c|}
\hline Parameter dan Satuannya & Batas Nilai \\
\hline Massa jenis pada $40^{\circ} \mathrm{C}, \mathrm{kg} / \mathrm{m}^{3}$ & $850-890$ \\
Viskositas kinematik pada $40^{\circ} \mathrm{C}$, & $2,3-6,0$ \\
$\mathrm{~mm}^{2} / \mathrm{s}$ (cSt) & \\
\hline Titik nyala (mangkok tertutup), ${ }^{\circ} \mathrm{C}$ & min. 100 \\
Gliserol bebas \%-massa & maks. 0,02 \\
Gliserol total \%-massa & maks. 0,24 \\
\hline
\end{tabular}

\section{Hasil}

\section{Analisa Bahan Baku Minyak Jelantah}

Bahan baku minyak jelantah ini dianalisis dengan menggunakan GC (Gas Chromatography) untuk mengetahui komposisi asam-asam lemak yang terkandung didalamnya dan untuk menghitung berat molekul minyak jelantah (dalam bentuk trigliserida). 


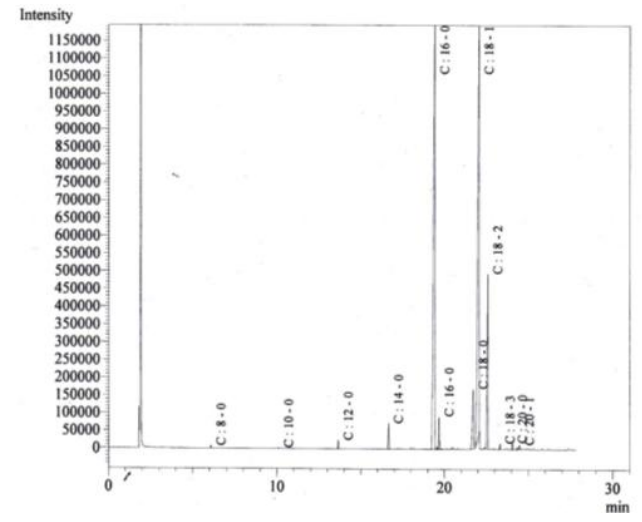

Gambar 3. Kromatogram Komposisi Asam Lemak Minyak Jelantah

Pada gambar 3 merupakan komposisi asam lemak hasil analisa GC. Dari kromatogram pada gambar 3 komposisi asam lemak minyak jelantah tersebut dapat dilihat pada tabel 3.

Tabel 3. Komposisi Asam Lemak dari Minyak Jelantah

\begin{tabular}{|c|c|c|}
\hline $\begin{array}{c}\text { Retention } \\
\text { Time } \\
\text { (menit) }\end{array}$ & $\begin{array}{l}\text { Komponen } \\
\text { Penyusun }\end{array}$ & $\begin{array}{c}\text { Komposisi } \\
\%(b / b)\end{array}$ \\
\hline 6,082 & $\begin{array}{l}\text { Asam Kaprilat } \\
\qquad\left(\mathrm{C}_{8: 0}\right)\end{array}$ & 0,1265 \\
\hline 10,098 & $\begin{array}{l}\text { Asam Kaproat } \\
\qquad\left(\mathrm{C}_{10: 0}\right)\end{array}$ & 0,0311 \\
\hline 13,648 & $\begin{array}{l}\text { Asam Laurat } \\
\left(\mathrm{C}_{12: 0}\right)\end{array}$ & 0,3722 \\
\hline 16,653 & $\begin{array}{l}\text { Asam Miristat } \\
\qquad\left(\mathrm{C}_{14: 0}\right)\end{array}$ & 1,0871 \\
\hline 19,405 & $\begin{array}{l}\text { Asam Palmitat } \\
\qquad\left(\mathrm{C}_{16: 0}\right)\end{array}$ & 39,7893 \\
\hline 19,688 & $\begin{array}{l}\text { Asam Palmitat } \\
\qquad\left(\mathrm{C}_{16: 0}\right)\end{array}$ & 1,4450 \\
\hline 21,713 & $\begin{array}{c}\text { Asam Stearat } \\
\left(\mathrm{C}_{18: 0}\right)\end{array}$ & 4,5168 \\
\hline 22,051 & Asam Oleat $\left(\mathrm{C}_{18: 1}\right)$ & 41,9186 \\
\hline 22,577 & $\begin{array}{c}\text { Asam Linoleat } \\
\left(\mathrm{C}_{18: 2}\right)\end{array}$ & 9,6923 \\
\hline 23,314 & $\begin{array}{l}\text { Asam Linolenat } \\
\qquad\left(\mathrm{C}_{18: 3}\right)\end{array}$ & 0,2870 \\
\hline 24,056 & $\begin{array}{l}\text { Asam Arakidat } \\
\qquad\left(\mathrm{C}_{20: 0}\right)\end{array}$ & 0,3446 \\
\hline 24,467 & $\begin{array}{c}\text { Asam Eikosenoat } \\
\left(\mathrm{C}_{20: 1}\right)\end{array}$ & 0,3896 \\
\hline
\end{tabular}

Berdasarkan hasil analisa GC, komponen asam lemak yang dominan pada sampel minyak jelantah adalah asam palmitat (C16:0) sebesar $39,7893 \%(\mathrm{~b} / \mathrm{b})$ dan asam oleat (C18:1) sebesar $41,9186 \%$ (b/b). Asam Lemak Bebas yang terdapat pada sampel Minyak Jelantah dapat dilihat pada tabel 4 .

Tabel 4. Kadar Asam Lemak Bebas Minyak Jelantah

\begin{tabular}{|c|c|c|}
\hline \multicolumn{3}{|c|}{ Kadar ALB (\%) } \\
\hline Sebelum & Sesudah & $\%$ \\
\hline Esterifikasi & Esterifikasi & Penurunan ALB \\
\hline 3,114 & 0,819 & 73,70 \\
\hline 3,209 & 0,86 & 73,20 \\
\hline 3,51 & 0,888 & 74,70 \\
\hline 3,619 & 0,901 & 75,10 \\
\hline 4,001 & 0,942 & 76,46 \\
\hline 4,124 & 0,956 & 76,82 \\
\hline
\end{tabular}

Dari tabel di atas dapat di lihat bahwa dengan esterifikasi maka ALB Minyak Jelantah menurun menjadi $<1 \%$.

\section{Analisa Yield}

Hubungan jumlah katalis (\%b/b) terhadap yield metil ester dapat di lihat pada gambar 4.

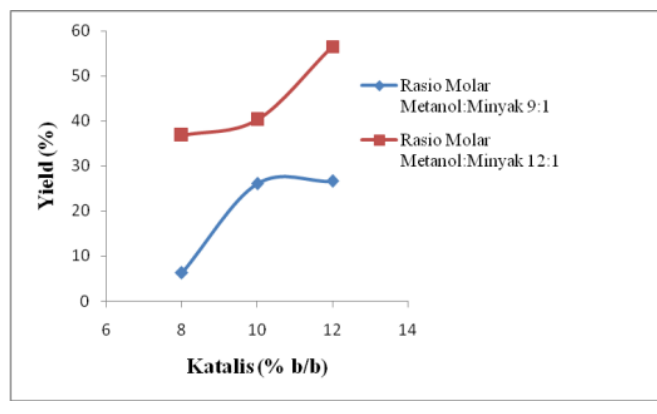

Gambar 4. Pengaruh Persen Katalis $(\% \mathrm{~b} / \mathrm{b})$ Terhadap Yield Metil Ester

Achanai, dkk., 2013 melakukan penelitian pembuatan metil ester tanpa katalis dengan waktu 2-6 jam dimana tidak ada metil ester yang dihasilkan [1]. Kemungkinan pembentukan metil ester dapat dilakukan tanpa katalis tetapi terbentuk metil ester dalam waktu yang cukup lama. Pada Gambar 4 dapat dilihat pengaruh katalis pada rasio molar metanol:minyak terhadap yield metil ester. Pada rasio molar metanol:minyak 9:1 katalis $8 \%$ menghasilkan yield metil ester sebanyak 6,3\%, dengan penambahan katalis $10 \%$ dan $12 \%$ mengalami kenaikan yield metil ester $25,71 \%$ dan $26,94 \%$. Pada rasio molar metanol:minyak 12:1 katalis $8 \%$ menghasilkan yield metil ester sebanyak 36,04\%, dengan penambahan katalis $10 \%$ dan $12 \%$ menghasilkan yield yang lebih besar. Hal ini menunjukan bahwa proses transesterifikasi minyak sangat tergantung oleh katalis kalsium oksida $(\mathrm{CaO})$ pada abu cangkang kerang. Yield 
metil ester yang besar diperkirakan katalis $\mathrm{CaO}$ yang bereaksi dengan metanol sudah membentuk senyawa kalsium metoksida secara menyeluruh yang dapat meningkatkan yield metil ester, sedangkan Yield metil ester yang lebih sedikit diperkirakan bahwa konsentrasi katalis $\mathrm{CaO}$ yang belum bereaksi dengan metanol semakin besar tidak menyebabkan bergesernya reaksi ke arah pembentukan metil ester namun menyebabkan kualitas pertemuan antar reaktan semakin meningkat yang dapat menurunkan keaktifan kalsium oksida sebagai katalis. Ikut bereaksinya kalsium oksida terhadap trigliserida membuat reaksi cenderung membentuk gliserol dan membentuk sabun. Reaksi penyabunan tersebut akan mengambil sejumlah metil ester yang telah terbentuk dan juga metil ester lainnya dimungkinkan terjebak dalam emulsi yang terbentuk sehingga gliserol dan sabun yang terbentuk lebih banyak daripada metil ester yang diperoleh $[6,10]$.

Dari gambar 4 dapat dilihat bahwa kondisi terbaik yang didapatkan adalah pada katalis sebesar $12 \%$ dengan Rasio molar metanol:minyak 12:1 memberikan yield metil ester yang paling tinggi yaitu sebesar 56,51\%. Hasil penelitian ini menggunakan abu cangkang kerang sebagai katalis menghasilkan yield dan kemurnian yang lebih tinggi dari penelitian sebelumnya yang melakukan pembuatan metil ester dari minyak jelantah dengan menggunakan katalis $\mathrm{CaO}$ yang dilakukan Hilary rutto dan Christopher enwerewadu pada rasio molar metanol:minyak 12:1 yang menghasilkan yield sebesar 46,92\% dan Aldes dkk tidak dapat menampilkan yield dan kemurnian pada penelitian yang dilakukan $[3,9]$.

\section{Analisa Kemurnian Metil Ester}

Hubungan jumlah katalis (\%b/b) terhadap kemurnian metil ester dapat di lihat pada gambar 5 .

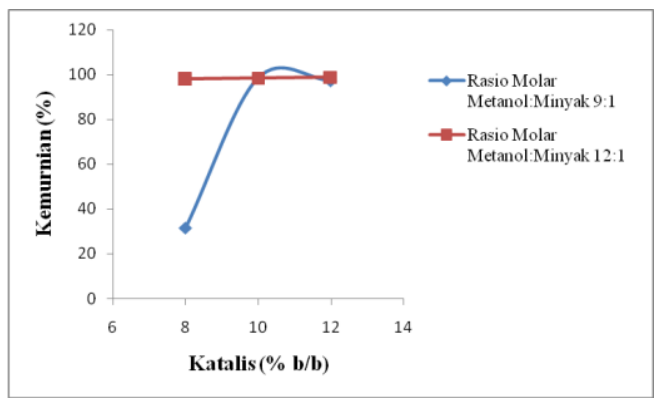

Gambar 5. Pengaruh Persen Katalis (\%b/b) Terhadap Kemurnian Metil Ester

Dari gambar 5 dapat dilihat pengaruh persen katalis abu cangkang kerang terhadap kemurnian metil ester. Grafik diatas menunjukkan pada rasio molar metanol : minyak 9:1, katalis $8 \%$ ke katalis $10 \%$ meningkatkan kemurnian metil ester yang dihasilkan $98,42 \%$ dan pada katalis $12 \%$ menghasilkan kemurnian yang menurun sebesar 97,33\%. Sedangkan pada rasio molar metanol:minyak $12: 1$, penambahan persen katalis dari $8 \%, 10 \%$, sampai $12 \%$ menghasilkan kemurnian metil ester yang meningkat terus. Diperoleh kemurnian metil ester tertinggi pada katalis $12 \%$ pada metanol:minyak 12:1 sebesar $98,79 \%$. Hal ini dikarenakan pada persen katalis $12 \%$ yang dicampur dengan metanol:minyak 12:1 yang membentuk kalsium metoksida yang banyak sehingga tumbukan antara molekul trigliserida dengan alkohol menjadi lebih efektif dan produk lebih cepat terbentuk dalam waktu tertentu [6]. Pada gambar 6 merupakan hasil analisa GC metil ester yang tertinggi.

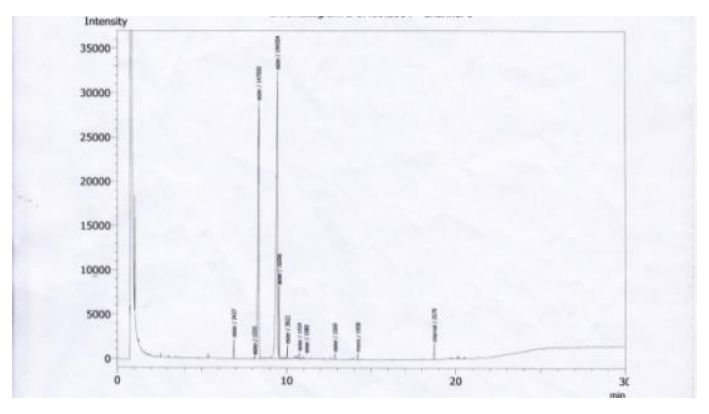

Gambar 6. Hasil Analisa GC menunjukkan kemurnian metil ester pada perbandingan mol:minyak 12:1, persen katalis $12 \%$

Hasil analisis dengan GC menunjukkan bahwa kemurnian metil ester yang dihasilkan sebanyak 98,79\%, sedangkan sisanya adalah monogliserida dan internal.

\section{Analisa Densitas}

Densitas merupakan besaran intensif yang berkaitan dengan nilai kalor dan daya yang di hasilkan oleh mesin diesel persatuan volume bahan bakar [11].

\section{Tabel 5. Densitas Metil Ester}

\begin{tabular}{|c|c|c|}
\hline $\begin{array}{c}\text { Katalis } \\
(\% \mathrm{~b} / \mathrm{b})\end{array}$ & $\begin{array}{c}\text { Densitas }\left(\mathrm{kg} / \mathrm{m}^{3}\right) \\
\text { Metanol:Minyak } \\
\text { dengan rasio 9:1 }\end{array}$ & $\begin{array}{c}\text { Densitas }\left(\mathrm{kg} / \mathrm{m}^{3}\right) \\
\text { Metanol:Minyak } \\
\text { dengan rasio 12:1 }\end{array}$ \\
\hline 8 & 887,69 & 873,37 \\
10 & 877,89 & 872,44 \\
12 & 874,62 & 856,26 \\
\hline
\end{tabular}

Dari tabel 5 menunjukkan bahwa semakin besar katalis abu cangkang kerang dan rasio molar yang besar menghasilkan densitas metil ester yang kecil. Hal ini disebabkan karena telah 
terjadi pemutusan gliserol dari trigliserida sehingga terbentuk senyawa dengan ukuran molekul yang lebih kecil.

Densitas merupakan besaran intensif yang berkaitan dengan nilai kalor dan daya yang di hasilkan oleh mesin diesel persatuan volume bahan bakar. Menurut Standar Nasional Indonesia (SNI 04-7182-2006) densitas metil ester pada suhu $40^{\circ} \mathrm{C}$ adalah $850-890 \mathrm{~kg} / \mathrm{m}^{3}$. Dari hasil penelitian, densitas metil ester yang diperoleh berkisar 856,26 - 877,89 $\mathrm{kg} / \mathrm{m}^{3}$. Dengan demikian, metil ester yang dihasilkan memenuhi standar metil ester. Jika metil ester mempunyai densitas melebihi ketentuan maka tidak dapat di gunakan untuk mesin diesel karena akan meningkatkan keausan mesin, emisi dan menyebabkan kerusakan pada mesin [7].

\section{Analisa Viskositas}

Viskositas minyak diesel yang tinggi dapat mempersulit proses pembentukan butir butir kabut pada saat atomisasi bahan bakar ke dalam mesin dan menyebabkan terjadinya proses pembakaran yang tidak sempurna, akan tetapi jika viskositas bahan terlalu rendah dapat menyebabkan kebocoran pada pompa injeksi bahan bakar. Adapun viskositas yang dihasilkan sebagai berikut :

Tabel 6. Viskositas Kinematik Metil Ester

\begin{tabular}{|c|c|c|}
\hline $\begin{array}{c}\text { Persen } \\
\text { Katalis } \\
(\% \mathrm{~b} / \mathrm{b})\end{array}$ & $\begin{array}{c}\text { Viskositas } \\
\text { Kinematik }(\mathrm{cSt}) \\
\text { Metanol:Minyak } \\
\text { dengan rasio 9:1 }\end{array}$ & $\begin{array}{c}\text { Viskositas } \\
\text { Kinematik }(\mathrm{cSt}) \\
\text { Metanol:Minyak } \\
\text { dengan rasio 12:1 }\end{array}$ \\
\hline 8 & 5,876 & 5,722 \\
10 & 5,873 & 5,102 \\
12 & 5,772 & 4,082 \\
\hline
\end{tabular}

Menurut Standar Nasional Indonesia (SNI 04-7182-2006), viskositas kinematik metil ester pada suhu $40^{\circ} \mathrm{C}$ adalah $2,3-6,0 \mathrm{cSt}$. Dari hasil penelitian yang diperoleh untuk berbagai variasi temperatur, viskositas kinematik metil ester yang diperoleh berkisar 4,082 - 5,876 cSt. Dari hasil penelitian yang diperoleh viskositas metil ester yang dihasilkan sesuai dengan standar viskositas kinematik biodiesel [2].

\section{Kesimpulan}

Dari hasil penelitian yang diperoleh dapat disimpulkan bahwa limbah cangkang kerang dapat digunakan sebagai katalis untuk sintesis metil ester. Pada penelitian ini, hasil maksimum biodiesel diperoleh sebanyak 56,51\% dengan kemurnian $98,79 \%$ yaitu pada reaksi menggunakan cangkang kalsinasi $900^{\circ} \mathrm{C}$ selama 3 jam, temperatur reaksi $65^{\circ} \mathrm{C}$, rasio mol metanol:minyak 12:1, reaksi selama 3 jam dan persen katalis $12 \%$.

\section{Daftar Pustaka}

[1] Achanai Buasri, Nattawut Chaiyut, Vorrada Loryuenyong, Phatsakon Worawanitcha phong, and Sarinthip Trongyong, Calcium Oxide Derived from Waste Shells of Mussel,Cockle, and Scallop as the Heterogeneous Catalyst for Biodiesel Production, The Scientific World Journal, Vol 2013.

[2] Agus Sundaryono., "Karakteristik Biodiesel Dan Blending Biodiesel Dari Oil Losses Cair Pabrik Minyak Kelapa Sawit”, J. Tek. Ind. Pert. Vol. 21 (1), 2005: hal 34-40.

[3] Aldes Lesbani, Risma Kurniawati M , Risfidian Mohadi, Produksi Biodiesel Melalui Reaksi Transesterifikasi Minyak Jelantah dengan Katalis Cangkang Kerang darah (Anadara granosa) Hasil Dekomposisi, Indonesian E-Journal of Applied Chemistry, Vol 1, No 2,2013:hal 1-7.

[4] Hendra D Tantra, Edo Tandean, Nani Indraswati, Suryadi Ismadji, Katalis Dari Limbah Kerang Batik (phapia undulata) Untuk Pembuatan Biodiesel dari Minyak Kelapa Sawit, Skripsi, Jurusan Teknik Kimia, Universitas Katolik Widya Mandala, 2011.

[5] Hilary Rutto dan Christopher Enweremadu, Optimization of production variables of biodiesel using calcium oxide as a heterogeneous catalyst: an optimized process, Department of Chemical Engineering, Vanderbijlpark Campus, Vaal University Of Technology, Department of Mechanical and Industrial Engineering, University of South Africa, 2013:hal 1-7.

[6] Isalmi Aziz, Siti Nurbayti, dan Badrul Ulum, Pembuatan produk biodiesel dari Minyak Goreng Bekas dengan Cara Esterifikasi dan Transesterifikasi, Program Studi Kimia FST UIN Syarif Hidayatullah Jakarta, 2011:hal 1-6.

[7] Muhammad Yusuf Ritonga, Doni Hermanto Sihombing, dan Allen Rianto Sihotang, Pengaruh Kadar Kalium Abu Kulit Abu Kelapa Dalam Mengkatalisis Reaksi Transesterifikasi Crude Palm Oil (CPO) Menjadi Metil Ester, Jurusan Teknik Kimia Universitas Sumatera Utara, 2013:hal 1-97.

[8] Satriana dan Muhammad D. Supardan, "Kinetic Study of Esterification of Free Acid in Low Grade Crude Palm Oil Using Sulfuric Acid", AJChe, 8(1),2008: hal. 1-8.

[9] Singh, S.P dan Singh, Dipti, Biodiesel production through the use of different 
sources and characterization of oils and their esters as the substitute of diesel: A review, journal homepage :www. elsevier.com/locate/rser, 14 (2010). Hal. 200-216, 2009.

[10] Sirichai Chantara-arpornchai, Apanee Luengnaruemitchai dan Samai Jai-In, "Biodiesel Production from Palm Oil Using Heterogeneous Base Catalyst", International Journal of Chemical and Biological Engineering 6(2012): hal 230-235.

[11] Tobing.E.R Mangisi, $\mathrm{CaO}$ dan $\mathrm{MgO}$ Sebagai Katalisator Terhadap Reaksi Transesterifikasi Minyak Jarak (Ricinus Communis) Menjadi Metil Ester Asam Lemak, Jurusan Kimia, Fakultas Matematika Dan Ilmu Pengetahuan Alam, Universitas Sumatera Utara, 2009.

[12] Zheng, S., Kates, M., Dubé, M. A., McLean, D. D., "Acid-Catalyzed Production Of Biodiesel From Waste Frying Oil", Biomass And Bioenergy, 30(1), 2006:hal. 267-272. 